\title{
HYPOTHESIS
}

\section{Importance of timing of risk factors for cerebral oedema during therapy for diabetic ketoacidosis}

\author{
A P C P Carlotti, D Bohn, M L Halperin
}

Arch Dis Child 2003;88:170-173

Cerebral oedema is the most common cause of mortality and morbidity during the first day of conventional treatment for diabetic ketoacidosis in paediatric patients. It is possible that therapy contributes to its development. Risk factors that predispose to cerebral oedema should lead to an expansion of the intracellular and/or the extracellular fluid compartment(s) of the brain because water normally accounts for close to $80 \%$ of brain weight. With respect to the intracellular fluid compartment, the driving force to cause cell swelling is a gain of effective osmoles in brain cells and/or a significant decline in the effective osmolality of the extracellular fluid compartment. Factors leading to an expansion of the intracerebral extracellular fluid volume can be predicted from Starling forces acting at the blood-brain barrier. Some of these risk factors have an early impact, while others have their major effects later during therapy for diabetic ketoacidosis. Based on a theoretical analysis, suggestions to modify current therapy for diabetic ketoacidosis in children are provided.

See end of article for authors' affiliations

\section{Dr M L Halperin, Division} of Nephrology, St Michael's Hospital, 38 Shuter Street, Toronto, Ontario, Canada M5B 1A6; mitchell.halperin@ utoronto.ca

Accepted 17 August 2002

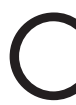
erebral oedema is a potentially devastating complication that occurs in the first day of therapy for diabetic ketoacidosis (DKA). ${ }^{12}$ It is commonly seen 5-15 hours after therapy begins, and there is often little warning that it might develop. Cerebral oedema should be suspected when there is an unexpected deterioration in neurological status or the persistence of a comatose state without an obvious cause. Therefore children with DKA should be admitted to a unit where they can be observed closely for a change in neurological status that includes the development of a headache or vomiting, a diminished ability to respond to questions, or worsening coma.

Cerebral oedema is primarily a clinical diagnosis. The presumptive diagnosis of cerebral oedema is more secure if there is a rapid improvement in neurological status in response to intravenous administration of $3 \% \mathrm{NaCl}$ or hypertonic mannitol. Making and acting on a clinical diagnosis should take precedence over performing a computed tomography (CT) scan because the latter might delay the implementation of emergency therapy. In fact, confirmatory changes of cerebral oedema on CT scan studies frequently do not keep pace with the clinical course, and they might not be sensitive enough to detect cerebral oedema. Moreover, care might suffer when the patient is transported to an area of the hospital where continuous monitoring may be less than ideal.

Risk factors for cerebral oedema were evaluated recently in two large, carefully conducted, retrospective reviews, ${ }^{12}$ where 61 and 34 patients respectively with cerebral oedema were identified. Cerebral oedema occurred in slightly less than $1 \%$ of children treated for DKA-mortality rate was 21 and 24\%, respectively. The risk of cerebral oedema appeared to be greater in younger and newly diagnosed diabetics. In the study of Glaser and colleagues, ${ }^{2}$ a higher plasma urea concentration, a lower arterial $\mathrm{pCO}_{2}$ (calculated from measured venous values with assumptions that are open to question when the arterial value was lacking), and therapy with sodium bicarbonate $\left(\mathrm{NaHCO}_{3}\right)$ were statistically associated with cerebral oedema. Of interest, their data as well as those of others ${ }^{134}$ suggested that a smaller increase in plasma sodium $\left(\mathrm{Na}^{+}\right)$concentration $\left(\mathrm{P}_{\mathrm{Na}}\right)$ during therapy may be associated with cerebral oedema.

The lack of a design for ideal treatment of paediatric patients presenting with DKA that minimises the risk of developing cerebral oedema was highlighted in two recent editorials. ${ }^{5}$ In both, the authors implied that current fluid and electrolyte management might contribute to the development of cerebral oedema. Part of the reason for this is that clinicians do not have good data to predict how large the deficits of $\mathrm{Na}^{+}, \mathrm{K}^{+}$, and water are likely to be in this population because they can be quite variable in individual patients. These facts make it almost impossible to select an ideal intravenous therapy for these patients. Nevertheless, in this as in other fluid and electrolyte disorders, one need not replace the entire deficit in a precise fashion or at "just the right rate" to minimise risks for the patient. Rather, one must not create a problem by having an inadequate or an excessively large/rapid infusion rate at a time when the patient is most vulnerable. Hence our aim is to provide a theoretical background that might help identify some of these risks, how they might interact, and of greatest importance, emphasise the importance of timing of each therapeutic modality.

For cerebral oedema to become life threatening, intracranial pressure (ICP) must rise appreciably. Five potentially important risk factors that

Abbreviations: $B B B$, blood-brain barrier; $C T$, computed tomography; DKA, diabetic ketoacidosis; ECF, extracellular fluid; ICF, intracellular fluid; ICP, intracranial pressure; $\mathrm{NHE}, \mathrm{Na}^{+} / \mathrm{H}^{+}$exchanger 


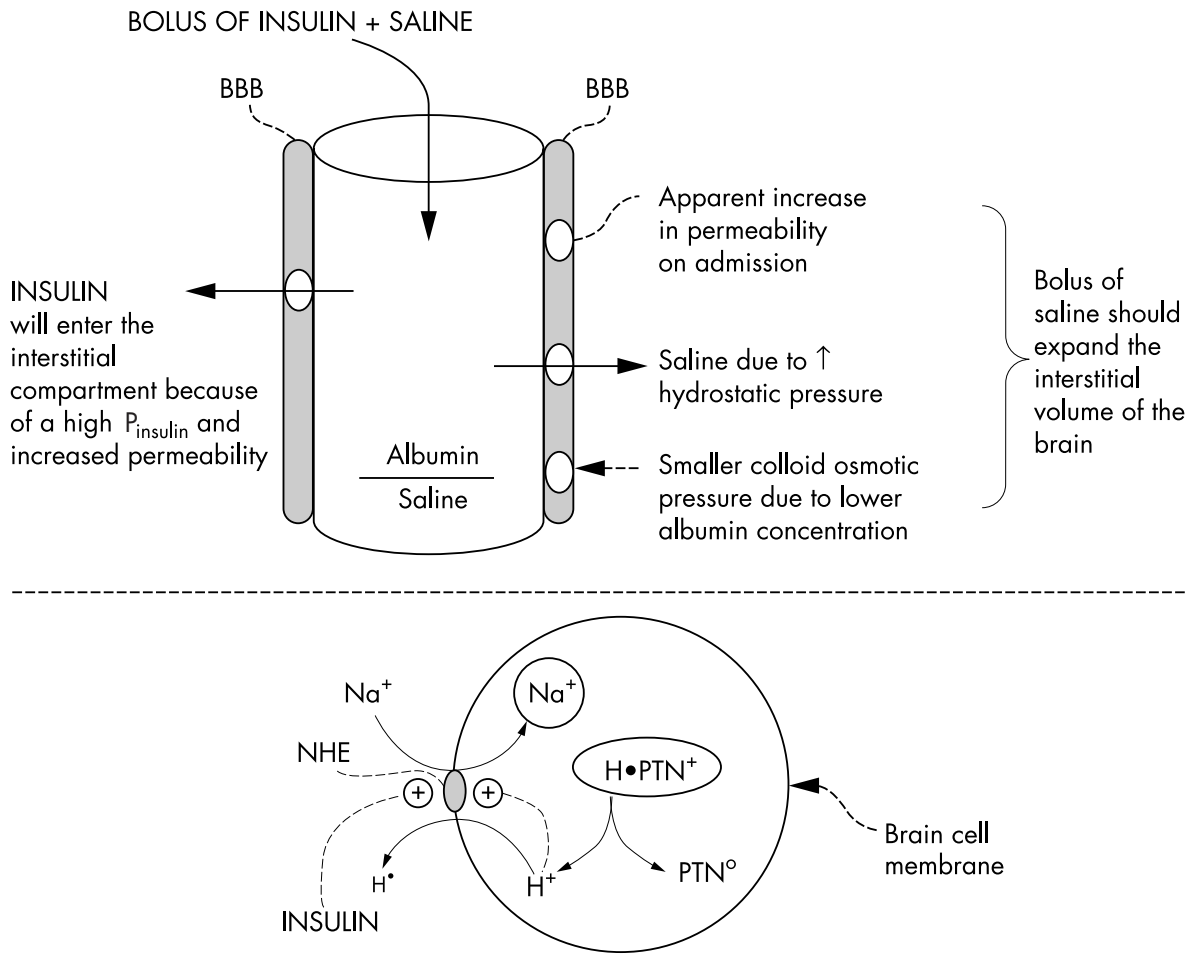

Figure 1 Early risk factors for the development of cerebral oedema. The top portion depicts the BBB that may be less restrictive early in therapy for DKA. Hence a bolus of saline could expand the intracranial interstitial volume. A bolus of insulin could expand the intracerebral ICF volume by converting the inactive form of $\mathrm{NHE}$ to its active form (bottom portion)-this causes $\mathrm{Na}^{+}$to enter and $\mathrm{H}^{+}$to exit from cells. One ultimate source of $\mathrm{H}^{+}$in the ICF is from macromolecules (proteins designated $\mathrm{H} \cdot \mathrm{PTN} \mathrm{N}^{+}$). The net result is the electroneutral and stoichiometric exchange of cations (a gain of monovalent $\mathrm{Na}^{+}$and the change in protein charge form a cationic to a less cationic form, depicted in the ICF ovals).

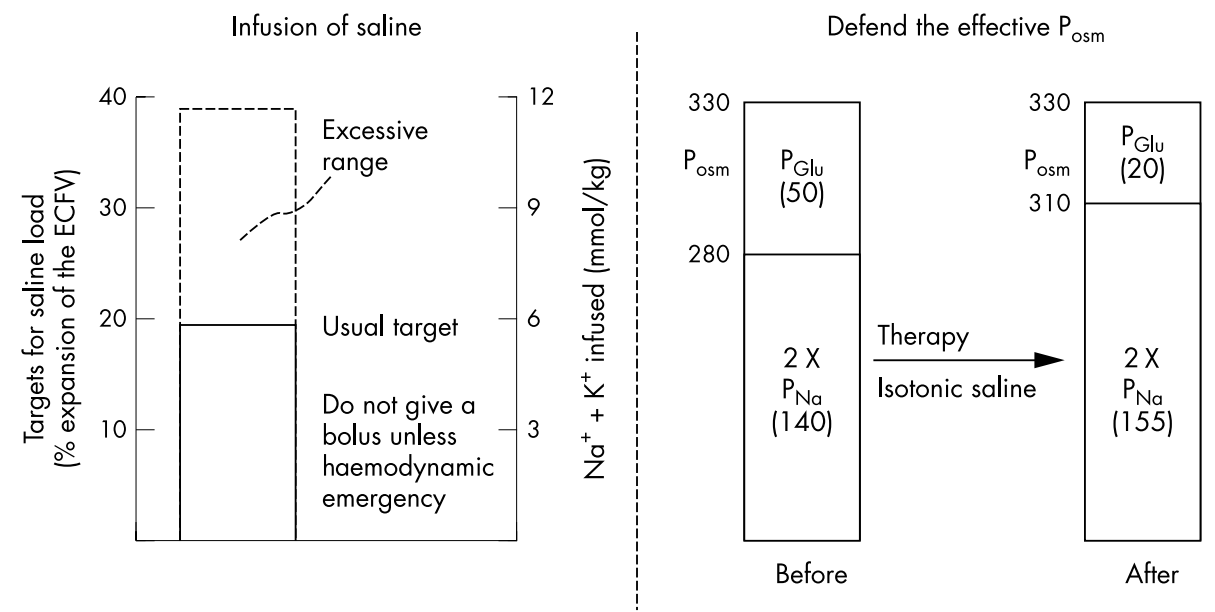

Figure 2 Late risk factors for the development of cerebral oedema. The risk associated with an infusion of too large a volume of saline (left portion) is expansion of the interstitial volume of the brain. If this occurs, the patient may develop an increased ICP even if there is a less severe degree of brain cell swelling. As shown in the right portion, a rise in $P_{N_{0}}$ is needed to prevent a fall in the effective $P_{\text {osm }}$ when there is a fall in $\mathrm{P}_{\mathrm{Glu}}$. The $\mathrm{P}_{\mathrm{Na}}$ must be $>140 \mathrm{mmol} / \mathrm{l}$ if the $\mathrm{P}_{\mathrm{Na}}$ on admission is close to $140 \mathrm{mmol} / \mathrm{l}$.

may contribute to the development of cerebral oedema will be emphasised because they may help to explain an increase in the intracerebral intracellular fluid (ICF) and/or extracellular fluid (ECF) volumes (figs 1 and 2). It is obvious that if one of these intracranial compartment volumes were to expand and if this were not accompanied by an equivalent decrease in the volume of the other, there would be a rise in ICP because the brain is enclosed in the skull. Each risk factor must be considered with respect to its magnitude, timing during therapy, and the presence of other risk factors, to understand why a clinically devastating rise in ICP occurred.
There are two major factors that could expand the ICF volume: a rise in the number of solute molecules restricted inside cells (effective osmoles) and a fall in the effective $\mathrm{P}_{\text {osm }}$ (equation 1) because water moves rapidly across cell membranes to achieve effective osmotic equilibrium. Prior to treatment of DKA, these effective ICF osmoles are primarily potassium $\left(\mathrm{K}^{+}\right)$, low molecular weight ICF anions, and glucose plus its metabolites. The ECF volume is determined primarily by the number of effective osmoles in this compartment $\left(\mathrm{P}_{\mathrm{Na}}\right.$ and the plasma glucose concentration $\left.\left(\mathrm{P}_{\mathrm{glu}}\right)\right){ }^{7}$ The interstitial compartment of the ECF can rise if there is a higher capillary hydrostatic pressure, a lower plasma colloid osmotic pressure, 
or capillaries that no longer effectively restrict the movement of albumin. Hence one can anticipate what the major factors leading to cerebral oedema will be.

Effective $P_{\text {osm }}=2\left(P_{\mathrm{Na}}\right)+\left(P_{\text {Glu }}\right)$ expressed in $\mathrm{mmol} / /$ terms

When assessing changes in the ECF volume, we shall express the rate of administration of intravenous saline as mmol $\mathrm{Na}^{+} / \mathrm{kg}$ body weight to facilitate comparisons in patients with different body sizes. For reference, if a $20 \mathrm{~kg}$ person has close to 4 litres of ECF ( $20 \%$ of body weight) and a $\mathrm{P}_{\mathrm{Na}}$ of $140 \mathrm{mmol} / \mathrm{l}$, there would be $560 \mathrm{mmol}$ of $\mathrm{Na}^{+}$per $20 \mathrm{~kg}$ in his ECF compartment (close to $30 \mathrm{mmol} \mathrm{Na} / \mathrm{kg}$ body weight). Thus a positive balance of $3 \mathrm{mmol} \mathrm{Na} / \mathrm{kg}$ expands the ECF volume by $10 \%$ if there is little change in the effective $\mathrm{P}_{\text {osm }}$. When comparisons are made, $3 \mathrm{mmol} \mathrm{Na} / \mathrm{kg}$ is equivalent to $20 \mathrm{ml}$ isotonic saline $/ \mathrm{kg}$ body weight.

\section{RISK FACTORS FOR CEREBRAL OEDEMA PRIOR TO THERAPY OF DKA}

The fact that cerebral oedema is present in close to $5 \%$ of patients prior to therapy for $\mathrm{DKA}^{12}$ strongly suggests that there are risk factors which might be present before therapy begins. We speculate that one of these factors is that the blood-brain barrier (BBB) might be less restrictive on admission in patients with DKA, because CT scans in several studies have shown a diminished diameter of the ventricular system prior to therapy for DKA. ${ }^{8-10}$ If this represents brain swelling, it was evident despite a contracted ECF volume (should shrink the brain ECF volume) and a higher effective $\mathrm{P}_{\text {osm }}$ (should diminish the ICF volume unless there was a large increase in ICF solutes in brain cells).

A fortuitous recent observation could provide insights into why cerebral oedema might develop in a specific patient prior to therapy for DKA. ${ }^{11}$ We reported data from a 17 year old female who had multiple admissions for DKA because she was not compliant with recommended therapy. On the last admission, she presented with an extremely high $\mathrm{P}_{\text {Glu }}(70 \mathrm{mmol} / \mathrm{l}$ ( $1260 \mathrm{mg} / \mathrm{dl})$ ), but she did not have obvious ketoacidosis. She excreted 1 litre of urine in the first 100 minutes in the emergency department. The major basis for her extremely large polyuria was a glucose induced osmotic diuresis that was likely caused by the intake of sweetened fruit juice. Her $\mathrm{P}_{\text {Glu }}$ at the start and end of this first 100 minute interval remained at $70 \mathrm{mmol} / \mathrm{l}$ and her $\mathrm{P}_{\mathrm{Na}}$ did not change appreciably-hence her effective $\mathrm{P}_{\text {osm }}$ was virtually constant. When she no longer had access to sweetened fruit juice in the emergency department, she drank tap water. In the next 100 minute period, there was a sudden fall in her effective $\mathrm{P}_{\text {osm }}$ because her $\mathrm{P}_{\text {Glu }}$ fell by 30 $\mathrm{mmol} / \mathrm{l}$ while there was only a minor change in her $\mathrm{P}_{\mathrm{Na}}$. This fall in effective $P_{\text {osm }}$ could represent a clinically occult basis for the development of cerebral oedema. ${ }^{11}$ To suspect its presence, a more detailed history of the type of fluid intake is needed in a patient with an extremely large urine output. By finding a change in the ingested fluid from sugar containing fruit juice to tap water, one might be alerted to the possibility that there was an occult fall in the effective $\mathrm{P}_{\text {osm }}$ (equation 1). Without this detailed history or without having the first two sets of blood values, the physician in the emergency department would not be aware of this potential risk factor for the development of cerebral oedema.

\section{RISK FACTORS FOR CEREBRAL OEDEMA EARLY IN THE THERAPY OF DKA \\ Infusion of saline}

With the background of a less restrictive BBB discussed above, dangers associated with a large intravenous bolus of saline can be anticipated by analysing Starling forces across capillary membranes (fig l, top portion). An intravenous bolus of saline distributes initially in the plasma volume and reaches the brain; there is little mixing with the large ECF compartment.
There are two major reasons for this saline bolus to cause the exit of fluid across the BBB into the interstitial fluid compartment of the brain. First, capillary hydrostatic pressure might be higher because of an expanded plasma volume. Second, the colloid osmotic pressure might fall because of lowering of the plasma albumin concentration by dilution. The colloid osmotic pressure is also influenced directly by the net valence on plasma proteins (the Donnan effect). Kamel and colleagues ${ }^{12}$ showed that a rapid infusion of saline caused a significant decline in the net anionic charge on plasma proteins. Based on this reasoning, it should be potentially dangerous to give a bolus of saline to children with DKA unless there was a definite haemodynamic indication to do so (for example, low blood pressure). In our experience, haemodynamic collapse is not common in children with DKA. If there is a haemodynamic indication, up to $3 \mathrm{mmol} \mathrm{NaCl}$ per $\mathrm{kg}$ isotonic saline should be infused over 90 minutes. Once the blood pressure stabilises, the rate of infusion of $\mathrm{NaCl}$ should be much slower, with an upper limit reaching a positive balance of $6 \mathrm{mmol}$ $\mathrm{NaCl}$ per kg over 24 hours to replace the likely deficit of $\mathrm{Na}^{+} .{ }^{13}$

\section{Bolus of insulin}

The $\mathrm{Na}^{+} / \mathrm{H}^{+}$exchanger (NHE) in cell membranes is normally inactive because it catalyses an electroneutral exchange and its substrates have a much higher concentration (ECF Na ${ }^{+}$and ICF $\mathrm{H}^{+}$) than its products (ICF $\mathrm{Na}^{+}$and ECF $\mathrm{H}^{+}$) in steady state (fig l, bottom portion). Following a large intravenous bolus of insulin, this NHE could become active. ${ }^{14} 15$ The other activator of NHE is a higher $\mathrm{H}^{+}$concentration in the ICF compartment. ${ }^{14}{ }^{15}$ When NHE is active, there should be a gain of $\mathrm{Na}^{+}$and a loss of $\mathrm{H}^{+}$in the ICF compartment; this will increase the number of solute molecules in the $\mathrm{ICF}^{16}$ because the bulk of the exported $\mathrm{H}^{+}$were bound primarily to ICF proteins or entered cells along with $\beta$-hydroxybutyrate on the monocarboxylic acid transporter (fig 1). ${ }^{17-19}$ Since intracellular acidosis is usually present in patients with DKA and there is an insulin receptor in the brain, ${ }^{20}$ an intravenous bolus of insulin could have a more dramatic intracerebral effect if it were given early on, when the BBB might be less restrictive to the passage of insulin..$^{8-10}$ Although large doses of insulin were given in the past to patients with a serious degree of DKA, the incidence of cerebral oedema was quite low. This might reflect a less aggressive infusion of saline and/or the administration of insulin by the subcutaneous route.

While $\mathrm{NaHCO}_{3}$ would lower the ECF $\mathrm{H}^{+}$concentration, this should only become important for $\mathrm{Na}^{+}$entry into brain cells when their NHE is activated. If true, a combination of a bolus of insulin together with $\mathrm{NaHCO}_{3}$ and administration of both early in time could make this "trio" become important risk factors. In contrast, if insulin and $\mathrm{NaHCO}_{3}$ were administered later when the $\mathrm{BBB}$ is more intact, they might be less likely to cause cerebral oedema.

\section{RISK FACTORS FOR CEREBRAL OEDEMA LATER IN THERAPY FOR DKA \\ Rapid fall in $\mathbf{P}_{\mathrm{glu}}$}

A rapid decline in $\mathrm{P}_{\text {Glu }}$ would be a risk factor if there were a slower decline in the concentration of glucose and related metabolites in the brain. ${ }^{38921}$ The actual importance of this risk factor is not clear because the major fall in $\mathrm{P}_{\text {Glu }}$ occurs much earlier than the clinical onset of cerebral oedema.

\section{Fall in effective $P_{\text {os }}$}

A fall in $\mathrm{P}_{\mathrm{Glu}}$ would lead to a decline in the effective $\mathrm{P}_{\mathrm{osm}}$ if $\mathrm{P}_{\mathrm{Na}}$ did not rise by an appropriate amount (fig 2 , right portion). The $\mathrm{P}_{\text {Glu }}$ usually falls by $5 \mathrm{mmol} / \mathrm{l} / \mathrm{h}$ over the initial six hours of therapy. If the $\mathrm{P}_{\text {Glu }}$ on admission were close to $50 \mathrm{mmol} / \mathrm{l}$, the decline in $\mathrm{P}_{\text {Glu }}$ would be close to $30 \mathrm{mmol} / \mathrm{l}$. To avoid a fall in the "effective" $\mathrm{P}_{\text {osm' }}$, the $\mathrm{P}_{\mathrm{Na}}$ must rise by $15 \mathrm{mmol} / \mathrm{l}$ or half the fall in $\mathrm{P}_{\mathrm{Glu}}(30$ $\mathrm{mmol} / \mathrm{l})$. This is not a problem when the $\mathrm{P}_{\mathrm{Na}}$ is close to 125 
$\mathrm{mmol} / \mathrm{l}$ with a blood sugar of $50 \mathrm{mmol} / \mathrm{l}$, which is common in adults with DKA. ${ }^{22}$ Therefore the target for the $\mathrm{P}_{\mathrm{Na}}$ would be 140 $\mathrm{mmol} / \mathrm{l}$ in an adult population. In contrast, because the initial $\mathrm{P}_{\mathrm{Na}}$ is often close to $140 \mathrm{mmol} / \mathrm{l}$ on admission in a paediatric patient with a $\mathrm{P}_{\mathrm{Glu}}$ close to $50 \mathrm{mmol} / \mathrm{l}^{23-25}$ there is a therapeutic dilemma. If the goal of therapy were to maintain a constant effective $\mathrm{P}_{\mathrm{osm}}$ over the initial 12-24 hours, $\mathrm{P}_{\mathrm{Na}}$ should rise to close to $155 \mathrm{mmol} / \mathrm{l}$ in these patients. This value itself tends to make clinicians uncomfortable with the need to defend the effective $\mathrm{P}_{\text {osm }}$ vigorously. Although limited data were available in our preliminary study, it seemed advisable to maintain a constant effective $\mathrm{P}_{\mathrm{osm}}$, because the eight patients who did not develop cerebral oedema had an effective $\mathrm{P}_{\text {osm }}$ of $341 \pm 7 \mathrm{mOsm} / \mathrm{kg} \mathrm{H}_{2} \mathrm{O}$ from the 7 to the 24 hour time $\left(\mathrm{P}_{\mathrm{Na}}\right.$ rose to $\left.156 \pm 1 \mathrm{mmol} / \mathrm{l}\right)$. In contrast, the six patients who developed cerebral oedema during therapy had a fall in their effective $P_{\text {osm }}$ to $307 \pm 7$ $\mathrm{mOsm} / \mathrm{kg} \mathrm{H} \mathrm{H}_{2} \mathrm{O}$ over this period $\left(\mathrm{P}_{\mathrm{Na}}\right.$ remained at $140 \pm 1 \mathrm{mmol} /$ l).

\section{CONCLUDING REMARKS}

Clinical management of DKA should change. Each mode of therapy should be administered aggressively only if it deals with a threat to life. The cautions listed below are most important in a paediatric population because they are at greater risk of developing cerebral oedema. A constant infusion rather than a bolus of insulin should be given as the only seconds to minutes emergency that is reversed by insulin is life threatening hyperkalaemia (see Halperin and colleagues ${ }^{26}$ ). Isotonic saline should be infused rapidly only if there is a significant degree of hypotension. An upper target for a positive $\mathrm{Na}^{+}$balance is $6 \mathrm{mmol} / \mathrm{kg}$ in the first 24 hours. Isotonic saline is the preferred intravenous solution during the first day because the aim is to prevent a fall in the effective $\mathrm{P}_{\mathrm{osm}}$. In our opinion, it is advisable to select an appropriate target for the rise in $\mathrm{P}_{\mathrm{Na}}$ to decrease the degree of fall in the effective $\mathrm{P}_{\mathrm{osm}}$. One must be vigilant concerning both the infusions given and the clinical picture, because if the CNS status does not continue to improve, cerebral oedema should be suspected. In this setting, we would give a rapid infusion of hypertonic saline or mannitol before there is irreversible brain damage. One should not limit the impression of the danger of cerebral oedema to mortality or gross cerebral function loss because cerebral oedema could lead to a loss of subtle cerebral functions that might not be easily recognised. Finally, this discussion points out a potential difficulty in interpreting data from large multicentre studies unless timing of therapy, prior deficits of $\mathrm{Na}^{+}$for instance (haemodynamic signs), and combinations of risk factors are included in the analysis.

\section{Authors' affiliations}

A P C P Carlotti, Department of Pediatrics, Universidade de Sao Paulo, Ribeirao Preto, Brazil

D Bohn, Department of Critical Care Medicine, The Hospital for Sick Children, and the Department of Anesthesia, University of Toronto, Toronto, Canada

M L Halperin, Renal Division, St Michael's Hospital, University of
Toronto, Toronto, Canada

This study was supported by a grant from the Canadian Institutes for Health Research (FRN 15485)

\section{REFERENCES}

1 Edge JA. Cerebral oedema during treatment of diabetic ketoacidosis: are we any nearer finding a cause? Diabetes Metab Res Rev 2000;16:316-24

2 Glaser N, Barnett $P, M_{c}$ Caslin I, et al. Risk factors for cerebral edema in children with diabetic ketoacidosis. N Engl J Med 2001;344:264-9

3 Hale PM, Rezvani I, Braunstein AW, et al. Factors predicting cerebral edema in young children with diabetic ketoacidosis and new onset type diabetes. Acta Paediatr 1997;86:626-31

4 Harris GD, Fiordalisi I, Harris WL, et al. Minimizing the risk of brain herniation during treatment of diabetic ketoacidosis: a retrospective and prospective study. J Pediatr 1990;117:22-31.

5 Inward CD, Chambers TL. Fluid management in diabetic ketoacidosis. Arch Dis Child 2002;86:443-4.

6 Edge J. Fluid management in diabetic ketoacidosis. Arch Dis Child 2002:86:444-5.

7 Halperin ML, Goldstein MB. Fluid, electrolyte and acid-base physiology; a problem-based approach. Philadelphia: WB Saunders, 1998.

8 Durr JA, Hoffman WH, Sklar AH, et al. Correlates of brain edema in uncontrolled IDDM. Diabetes 1992;41:627-32.

9 Hoffman WH, Steinhart CM, Gammal TE, et al. Cranial CT in children and adolescents with diabetic ketoacidosis. Am J Neuroradiol 1988:9:733-9.

10 Krane EJ, Rockoff MA, Wallman LK, et al. Subclinical brain swelling in children during the treatment of diabetic ketoacidosis. N Engl J Med 1985;312:1 147-51

11 Davids MR, Edoute Y, Stock S, et al. Severe degree of hyperglycemia: novel insights revealed by the use of simple principles of integrative physiology. QJM 2002;95:113-24.

12 Kamel KS, Cheema-Dhadli S, Halperin FA, et al. Anion gap: do the anions restricted to the intravascular space have modifications in their valence? Nephron 1996:73:382-9.

13 Danowski T, Peters J, Rathbun J, et al. Studies in diabetic acidosis and coma, with particular emphasis on the retention of administered potassium. J Clin Invest 1949;28: 1-9.

14 Soleimani $M$, Sing G. Physiologic and molecular aspects of the $\mathrm{Na}^{+} / \mathrm{H}^{+}$ exchangers in health and disease processes. J Investig Med 1995;43:419-30.

15 Moore RD. Stimulation of $\mathrm{Na}: \mathrm{H}$ exchange by insulin. Biophys J $1981 ; 33: 203-10$

16 Van der Meulen JA, Klip A, Grinstein S. Possible mechanism for cerebral oedema in diabetic ketoacidosis. Lancet 1987;ii:306-8.

17 Juel C, Halestrap AP. Lactate transport in skeletal muscle-role and regulation of the monocarboxylate transporter. J Physiol 1999;517:633-42.

18 Swan RC, Pitts RF. Neutralization of infused acid by nephrectomized dogs. J Clin Invest 1955;34:205-12.

19 Vasuvattakul S, Warner LC, Halperin ML. Quantitative role of the intracellular bicarbonate buffer system in response to an acute acid load. Am J Physiol 1992;262:R305-9.

20 Yip CC, Moule ML, Yeung CWT. Characterization of insulin receptor subunits in brain and other tissues by photoaffinity labeling. Biochem Biophys Res Commun 1980;96:1671-8.

21 Rosenbloom AL. Intracerebral crises during treatment of diabetic ketoacidosis. Diabetes Care 1990;13:22-33.

22 Roscoe JM, Halperin ML, Rolleston FS, et al. Hyperglycemia-induced hyponatremia: metabolic considerations in calculation of serum sodium depression. CMA 1975;112:452-3.

23 Carlotti APCP, Bohn D, Halperin ML. Factors predisposing to cerebral edema $(C E)$ in children presenting with a severe degree of diabetic ketoacidosis (DKA). J Am Soc Nephrol 1999;10:121A.

24 Mahoney CA. Extreme gestational starvation ketoacidosis: case report and review of pathophysiology. Am J Kidney Dis 1992;20:276-80.

25 Felner EI, White PC. Improving management of diabetic ketoacidosis in children. Pediatrics 2001;108:735-40

26 Halperin ML, Cherney DZI, Kamel KS. Ketoacidosis. In: DuBose TD Jr, Hamm LL, eds. Acid-base and electrolyte disorders: a companion to Brenner and Rector's, The Kidney. Philadelphia: WB Saunders, 2002. 